\title{
Prevalence of thalassaemia, iron-deficiency anaemia and glucose-6-phosphate dehydrogenase deficiency among Arab migrating nomad children, southern Islamic Republic of Iran
}

\author{
M. Pasalar, ${ }^{1}$ D. Mehrabani, ${ }^{2}$ A. Afrasiabi, ${ }^{1}$ Z. Mehravar, ${ }^{1}$ I. Reyhani, ${ }^{2}$ R. Hamidi ${ }^{1}$ and M. Karimi ${ }^{1}$
}

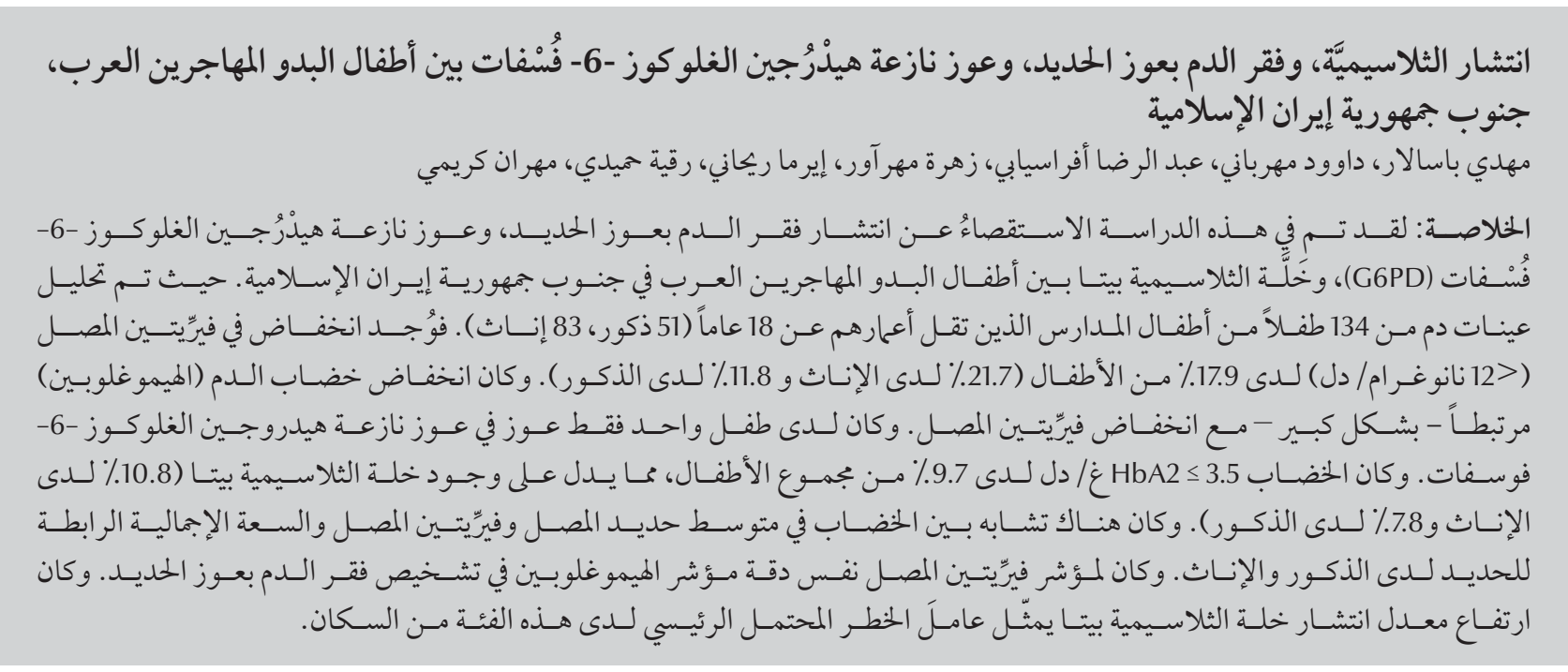

ABSTRACT This study investigated the prevalence of iron-deficiency anaemia, glucose-6-phosphate dehydrogenase (G6PD) deficiency and $\beta$-thalassaemia trait among Arab migrating nomad children in southern Islamic Republic of Iran. Blood samples were analysed from 134 schoolchildren aged $<18$ years ( 51 males, 83 females). Low serum ferritin $(<12 \mathrm{ng} / \mathrm{dL}$ ) was present in $17.9 \%$ of children (21.7\% in females and $11.8 \%$ in males). Low haemoglobin (Hb) correlated significantly with a low serum ferritin. Only 1 child had G6PD deficiency. A total of $9.7 \%$ of children had HbA2 $\geq 3.5 \mathrm{~g} /$ $\mathrm{dL}$, indicating $\beta$-thalassaemia trait (10.8\% in females and $7.8 \%$ in males). Mean serum iron, serum ferritin and total iron binding capacity were similar in males and females. Serum ferritin index was as accurate as $\mathrm{Hb}$ index in the diagnosis of iron-deficiency anaemia. A high prevalence of $\beta$-thalassaemia trait was the major potential risk factor in this population.

Prévalence de la thalassémie, de l'anémie ferriprive et du déficit en glucose-6-phosphate déshydrogénase chez des enfants nomades et migrants arabes (sud de la République islamique d'Iran)

RÉSUMÉ La présente étude a évalué la prévalence de l'anémie ferriprive, du déficit en glucose-6-phosphate déshydrogénase et de la bêta-thalassémie mineure chez des enfants nomades et migrants arabes dans le sud de la République islamique d'Iran. Des échantillons de sang de 134 écoliers de moins de 18 ans ont été analysés (51 garçons, 83 filles). Des taux de ferritine sérique faibles $(<12 \mathrm{ng} / \mathrm{dL})$ ont été observés chez 17,9\% des enfants ( $21,7 \%$ chez les filles et $11,8 \%$ chez les garçons). Un faible taux d'hémoglobine $(\mathrm{Hb})$ était significativement corrélé à un faible taux de ferritine sérique. Seul un enfant était atteint de déficit en glucose-6-phosphate déshydrogénase. Au total, 9,7 \% des enfants présentaient un taux d'HbA2 supérieur ou égal à 3,5 g/dL, signe d'une bêta-thalassémie mineure ( $10,8 \%$ des filles et 7,8 \% des garçons). Le taux moyen de fer sérique, de la ferritine sérique et la capacité de liaison du fer total étaient similaires chez les deux sexes. Le taux de ferritine sérique était aussi précis que le taux d’Hb pour le diagnostic de l'anémie ferriprive. La forte prévalence de la bêta-thalassémie mineure représentait le principal facteur de risque dans cette population. 


\section{Introduction}

There are a number of different nomad tribes of different ethnicities in the Islamic Republic of Iran and the haematological problems of their children may not be the same as in the wider community. Beta-thalassaemia is a common health problem in the Islamic Republic of Iran (1) which drastically affects the family and personal life of sufferers and is a drain on health resources (2). Betathalassaemia is caused by a deficient synthesis of $\beta$-chains of haemoglobin leading to hypochromic microcytic red cells, ineffective erythropoiesis and haemolytic anaemia and is the result of a decrease in haemoglobin $\mathrm{Hb}) \mathrm{F}$ synthesis during the first year of life (3). There have been several studies on $\beta$-thalassaemia mutation spectrum in the Iranian population since 1997 when the national thalassaemia screening programme was implemented $(2,4)$. Up to the end of 2001, 2.7 million prospective couples had been screened and 10298 at-risk couples had been identified, showing acceptable coverage of screening plus an annual $7.4 \%$ increase in the number of people reaching marriageable age. The average prevalence of carrier couples detected increased from $3.0 / 1000$ to $4.5 / 1000$ (5).

Iron-deficiency anaemia too is a common haematological problem worldwide, and is a public health problem in many developing countries. It is estimated that more than 500 million people worldwide are affected by irondeficiency anaemia (6).

Glucose-6-phosphate dehydrogenase (G6PD) deficiency is another important haematological disorder in the Islamic Republic of Iran, where it is a major public health problem in many areas (7). G6PD is an Xchromosome linked disorder, leading to acute haemolytic anaemia following ingestion of fava beans, certain drugs and bacterial or viral infections (8).
Nutritional deficiency, familial marriage, illiteracy and certain cultural beliefs in different nomadic groups may produce variations in the prevalence of thalassaemia, G6PD deficiency and iron-deficiency anaemia $(9,10)$. National data collection from different nomadic groups may help in planning health services more efficiently. The aim of this study was to investigate the prevalence of iron-deficiency anaemia, $\beta$-thalassaemia, and G6PD deficiency in Arab migrating nomads in Fars Province, southern Islamic Republic of Iran.

\section{Methods}

\section{Sample}

This cross-sectional study was conducted on Arab migrating nomad children in rural areas of Fars province in the southern part of the Islamic Republic of Iran. These nomads migrate between summer and winter quarters each year by up to $500 \mathrm{~km}$. A total of 134 schoolchildren in the age range 6-18 years were recruited from all 17 Arab nomad schools in the region. Their ethnicity determined by their registration in selected schools for Arab nomads. The total Arab students registered in any of schools were selected by their identification number using a computer program through simple random sampling, without replacements. According to our previous local data and the following statistical formula, the consultant statistician calculated 133 persons as the sample size:

$$
n=\left[Z^{2}(1-\alpha / 2) \times P(1-P)\right] / d^{2}
$$

with confidence interval $=95 \%, d=5.1 \%$ and $P=10 \%$.

The entire study group were of the same middle socioeconomic class and known to have a moderate-calorie diet intake. We excluded students who had any recognized haematological disease.

The study was approved by the ethics committee of Shiraz University of Medical Sciences. Written consent was taken from each student within the legal age range and the remaining participants signed the consent with their parents signing as witnesses. None of the selected students refused participation in the study.

\section{Data collection}

The study was performed over a 6-month period from March to July 2012. Data collection and blood sampling were performed by 3 of the current authors at the students' schools.

The students were interviewed concerning family history of thalassaemia and G6PD deficiency, signs and symptoms of iron-deficiency anaemia and anaemia, such as pica, agitation, anorexia and pale conjunctiva, and also availability of safe (piped, potable) drinking water. For young children, their parents answered the questions.

A $5 \mathrm{~mL}$ blood sample was collected from the participants by antecubital venepuncture and put in an icebox and immediately transported to Dastgheyb Hospital laboratory (affiliated to Shiraz University of Medical Sciences) for analysis.

Routine haematological parameters were measured immediately after blood sampling using an automated cell counter (Sysmex K1000 haematology analyser). These included: red blood cell (RBC) count, haemoglobin ( $\mathrm{Hb})$, haematocrit (Hct), mean corpuscular volume (MCV), mean corpuscular haemoglobin $(\mathrm{MCH})$, mean corpuscular haemoglobin concentration (MCHC) and red-cell distribution width (RDW). Serum iron and total iron binding capacity (TIBC) were determined by a calorimetric procedure, and serum ferritin was determined by enzyme-linked immunosorbent assay method (Dynex). The degree of G6PD deficiency was measured by fluorescent spot testing. Determination of different kinds of haemoglobin was performed using high performance liquid chromatography (Hb-Gold). 
Haemoglobin alpha-2 (HbA2) $\geq$ $3.5 \mathrm{~g} / \mathrm{dL}$ was considered diagnostic of $\beta$-thalassaemia trait. MCV $<80 \mathrm{fL}$, $\mathrm{MCH}<27$ pg and $\mathrm{Hb} \mathrm{A} 2 \geq 3.5 \%$ were considered as criteria for diagnosis of beta-thalassaemia. Anaemia was defined as $\mathrm{Hb}$ concentration below the World Health Organization cutoff for age and sex, i.e. $<12 \mathrm{~g} / \mathrm{dL}$ for females and 6-14-year-old males, and $<13 \mathrm{~g} / \mathrm{dL}$ for 15 -year-old males. The degrees of iron deficiency was determined by the following criteria: iron depletion was defined as serum ferritin concentration $<12 \mathrm{ng} / \mathrm{mL}$; and iron deficiency anaemia as anaemia accompanied by serum ferritin $<12$ $\mathrm{ng} / \mathrm{mL}$.

\section{Data analysis}

Pearson correlation test was performed to examine the association of $\mathrm{Hb}$ concentration with serum ferritin. Statistical analysis was performed using SPSS software, version 18. Student $t$-test used to compare the mean values of male and female participants. Statistical significance was set at $P<0.05$.

\section{Results}

Out of 134 schoolchildren 51 (38.1\%) were male and 83 (61.9\%) were female. The mean age of participants was 11.7 (SD 3.5) years, and the age range was 6-18 years, including 48 primary (6-11 years), 35 intermediate ( $12-15$ years) and 51 secondary schoolchildren (16-17 years).

Regarding risk factors related to anaemia, 33 (24.6\%) children did not have access to safe drinking water; 6 (4.5\%) had a family history of thalassaemia and 4 (3.0\%) had a family history of favism. The prevalence of symptoms which by themselves are non-specific, but are related to iron deficiency, was relatively high (Table 1).

The mean $\mathrm{HbA} 2$ level of the children was 2.7\% (SD 0.8\%), Hb was 13.1 (SD 1.3) g/dL and Hct was 42.8\% (SD

\begin{tabular}{lrrrr}
\hline $\begin{array}{l}\text { Table 1 Prevalence of different risk factors related to anaemia in Arab migrating } \\
\text { nomad schoolchildren }(\boldsymbol{n}=\mathbf{1 3 4})\end{array}$ & Yes & \multicolumn{3}{c}{ No } \\
\hline Parameter & No. & $\%$ & No. & $\%$ \\
& 101 & 75.4 & 33 & 24.6 \\
Availability of safe drinkable water & 6 & 4.5 & 128 & 95.5 \\
Family history of thalassaemia & 4 & 3.0 & 130 & 97.0 \\
Family history of favism & 24 & 17.9 & 110 & 82.1 \\
Pica & 12 & 9.0 & 122 & 91.0 \\
Anorexia & 43 & 32.1 & 91 & 67.9 \\
Agitation & 25 & 18.7 & 109 & 81.3 \\
Pallor & & & &
\end{tabular}

$3.1 \%$ ) (Table 2). The mean serum ferritin was $27.3(\mathrm{SD} 23) \mathrm{ng} / \mathrm{dL}$.

The mean $\mathrm{Hb}$ levels of males [13.6 $(\mathrm{SD} 1.2) \mathrm{g} / \mathrm{dL}$ ] were significantly higher than for female children [12.7 $(\mathrm{SD} 1.3) \mathrm{g} / \mathrm{dL}](P<0.001)$ and so were the Hct $[44.5 \%$ (SD 2.6\%) versus 41.8\% (SD 2.9\%) respectively] $(P<$ $0.001)$ and MCHC values [30.6 (SD 1.6) $\mathrm{g} / \mathrm{dL}$ versus $29.2(\mathrm{SD} 3.2) \mathrm{g} / \mathrm{dL}$ respectively] $(P=0.004)$. None of the other parameters (MCV, MCH, RDW, $\mathrm{HbA} 2, \mathrm{HbF}$, serum iron, serum ferritin and TIBC) showed significant differences between males and females

Among the participants, only 1 child had G6PD deficiency (Table 3). A total of 24 children (17.9\%) had serum ferritin $<12 \mu \mathrm{g} / \mathrm{dL}$ (Table 3 ), and the prevalence of low serum ferritin was higher in females than males (21.7\% versus $11.8 \%)$, although the difference was not statistically significant $(P=0.223)$. The prevalence of low $\mathrm{Hb}$ showed a statistical correlation with low serum ferritin $(P<0.05)$. A total of 13 children (9.7\%) had HbA2 levels $\geq 3.5 \%$ and the prevalence of $\beta$-thalassaemia trait was higher, but not significantly so, in female than male children ( $10.8 \%$ versus $7.8 \%$ ) $(P=0.787)$ (Table 3$)$.

\section{Discussion}

As the results indicate, 1 student had G6PD disorder (0.7\%) and 24 (17.9\%) showed low serum ferritin $(<12 \mu \mathrm{g} /$ $d L)$, indicative of iron-deficiency anaemia. The mean serum ferritin in our study was 27.3 (SD 23) ng/dL. Thirteen participants had $\mathrm{HbA} 2 \geq 3.5 \mathrm{~g} / \mathrm{dL}$ and therefore $9.7 \%$ of our sample were classified as having $\beta$-thalassaemia trait. The mean HbA2 level was 2.7\% (SD $0.8 \%$ ) in the current research. The mean levels of $\mathrm{Hb}, \mathrm{Hct}$ and $\mathrm{MCHC}$ showed statistically significant differences between male and female students, while other haematological parameters and iron indices showed no significant differences. The low $\mathrm{Hb}$ and Hct values correlated significantly with low serum ferritin $(P<0.05)$. Hence, it seems that serum ferritin index is as accurate as the $\mathrm{Hb}$ index in the diagnosis of irondeficiency anaemia.

The prevalence of iron-deficiency anaemia in our research was $17.9 \%$. This figure is consistent with previous reports in southern Islamic Republic of Iran (9-12), but is lower or higher than the prevalence found in other developing countries $(13,14)$. The prevalence of iron-deficiency anaemia in developed courtiers has declined in recent decades, but there has been little change in developing countries. The most common reason for iron-deficiency anaemia in children is poor intake of iron in the diet. This finding is particularly prominent in developing countries where the low level of iron intake is accompanied by malaria and intestinal parasitic infestations (15). There is a big difference in the prevalence of iron-deficiency 


\begin{tabular}{|c|c|c|c|c|}
\hline Parameter & $\begin{array}{l}\text { Males } \\
(n=51)\end{array}$ & $\begin{array}{c}\text { Females } \\
(n=83)\end{array}$ & $\begin{array}{c}\text { Total } \\
(n=134)\end{array}$ & $P$-value \\
\hline & Mean (SD) & Mean (SD) & Mean (SD) & \\
\hline Hct (\%) & $44.5(2.6)$ & $41.8(2.9)$ & $42.8(3.1)$ & $<0.001$ \\
\hline $\mathrm{Hb}(\mathrm{g} / \mathrm{dL})$ & $13.6(1.2)$ & $12.7(1.3)$ & $13.1(1.3)$ & $<0.001$ \\
\hline $\operatorname{MCV}(\mathrm{fL})$ & $83.6(6.1)$ & $81.5(7.6)$ & $82.3(7.1)$ & 0.097 \\
\hline MCH (pg/cell) & $25.7(2.8)$ & $25.1(3.1)$ & $25.3(3.0)$ & 0.261 \\
\hline RDW (\%) & $13.8(1.8)$ & $13.7(1.8)$ & $13.7(1.8)$ & 0.755 \\
\hline $\mathrm{MCHC}(\mathrm{g} / \mathrm{dL})$ & $30.6(1.6)$ & $29.2(3.2)$ & $29.8(2.8)$ & 0.004 \\
\hline $\mathrm{HbA2}(\mathrm{g} / \mathrm{dL})$ & $2.6(0.7)$ & $2.7(0.9)$ & $2.7(0.8)$ & 0.499 \\
\hline $\mathrm{HbF}(\mathrm{g} / \mathrm{dL})$ & 0.5 & 0.5 & 0.5 & - \\
\hline Serum iron $(\mu \mathrm{g} / \mathrm{dL})$ & $89.2(39.5)$ & $91.4(35.1)$ & $90.5(36.7)$ & 0.737 \\
\hline TIBC ( $\mu \mathrm{g} / \mathrm{dL})$ & $319.8(28.6)$ & $325.4(44.6)$ & $323.2(46.2)$ & 0.424 \\
\hline Serum ferritin $(\mu \mathrm{g} / \mathrm{dL})$ & $30.5(28.6)$ & $25.4(18.6)$ & $27.3(23.0)$ & 0.213 \\
\hline
\end{tabular}

$H c t=$ haematocrit; $H b=$ haemoglobin; $M C V=$ mean corpuscular volume; $M C H=$ mean corpuscular haemoglobin; $R D W$ red-cell distribution width; $M C H C=$ mean corpuscular haemoglobin concentration; HbA2 = haemoglobin alpha-2; HbF= haemoglobin F; TIBC= total iron binding capacity.

$S D=$ standard deviation

anaemia between developing and industrialized countries. In a study by Jain et al. the prevalence of irondeficiency anaemia was 59.9\% in India (13), while in a nutritional investigation in Madrid, Spain, the prevalence of iron-deficiency anaemia and iron deficiency state were $0.94 \%$ and $4.94 \%$ respectively (16). Although the prevalence of iron-deficiency anaemia in this study of Arab migrating nomads of the southern Islamic Republic of Iran is lower than the prevalence found in some other developing countries (17), it is still alarmingly high. Therefore, improved nutrition and educational programmes by the public health authorities may help to decrease the risk of iron deficiency and iron-deficiency anaemia.

A family history of favism was reported for $3.0 \%$ of children. Favism has been reported as a common disease in some northern (13) and southern regions of the Islamic Republic of Iran $(14,15)$. Newborn screening in a tertiary-care centre in north Lebanon showed a prevalence of favism of $2.1 \%$ $(62 / 3009)$, significantly higher in males than females (18).
In Sana'a, Yemen, of the total 508 male blood donors recruited into a study, 36 were G6PD deficient, giving a likely G6PD deficiency prevalence of 7.1\% (19). In Thailand, 4 and 7 G6PD variants were observed in samples collected from Burmese and Thai populations, with a prevalence of G6PD of $6.6 \%(21 / 317)$ and $14.2 \%(26 / 183)$ in the different populations respectively (20). In Saudi Arabia, the prevalence of G6PD deficiency was reported to be 6.9\% (21). The current study showed a much lower prevalence than the abovementioned reports. We only found only

\begin{tabular}{|c|c|c|c|c|c|c|}
\hline \multirow[t]{2}{*}{ Parameter } & \multicolumn{2}{|c|}{$\begin{array}{l}\text { Males } \\
(n=51)\end{array}$} & \multicolumn{2}{|c|}{$\begin{array}{l}\text { Females } \\
(\boldsymbol{n}=\mathbf{8 3})\end{array}$} & \multicolumn{2}{|c|}{$\begin{array}{c}\text { Total } \\
(n=134)\end{array}$} \\
\hline & No. & $\%$ & No. & $\%$ & No. & $\%$ \\
\hline \multicolumn{7}{|c|}{ G6PD deficiency } \\
\hline Present & 1 & 2.0 & 0 & 0.0 & 1 & 0.7 \\
\hline Absent & 50 & 98.0 & 83 & 100.0 & 133 & 99.3 \\
\hline \multicolumn{7}{|c|}{ Serum ferritin level $(\mu \mathrm{g} / \mathrm{dL})$} \\
\hline$<12$ & 6 & 11.8 & 18 & 21.7 & 24 & 17.9 \\
\hline$\geq 12$ & 45 & 88.2 & 65 & 78.3 & 110 & 82.1 \\
\hline \multicolumn{7}{|c|}{ HbA2 level (g/dL) } \\
\hline$<3.5$ & 47 & 92.2 & 74 & 89.2 & 121 & 90.3 \\
\hline$\geq 3.5$ & 4 & 7.8 & 9 & 10.8 & 13 & 9.7 \\
\hline
\end{tabular}

$G 6 P D=$ glucose-6-phosphate dehydrogenase $;$ HbA2 = haemoglobin alpha- 2 . 
1 case of G6PD deficiency in our study, in a male child. The prevalence of G6PD deficiency was $0.74 \%$, which is lower than some data reported from highprevalence areas in northern and southern regions of the Islamic Republic of Iran $(9,10)$. The difference from other studies may be due to variations in age groups studied, or to sociocultural or climate differences between the regions.

The prevalence of $\beta$-thalassaemia trait was $9.7 \%$ in our study, which is higher than in previous findings in nomads in southern Islamic Republic of Iran $(9,10)$. The rate of $\beta$-thalassaemia carriage has a wide range worldwide. In Bangladesh, it was reported to be as high as 28\% (17). In Malaysia, it was estimated that $4.5 \%$ of the population were carriers for thalassaemia, and this is similar to our finding (22). In Turkey the frequency of $\beta$-thalassaemia carriers in the city of Adryaman was low (1.91\%) (23).

Although most patients who have $\beta$-thalassaemia trait are asymptomatic and are found accidentally by a minor decrease in $\mathrm{Hb}$ level and MCV, the detection of such cases is important in the prevention of $\beta$-thalassaemia major. In the Islamic Republic of Iran, marriage registrars routinely refer prospective couples to a designated local laboratory for premarital screening. The man's red cell indices are checked first. If he has a microcytic cells (mean corpuscular haemoglobin $<27$ pg or mean corpuscular red volume $<80 \mathrm{fL}$ ) the woman is tested. When both the man and woman are microcytic, $\mathrm{HbA} 2$ concentration would then be measured. If both have a concentration of $\geq 3.5 \mathrm{~g} / \mathrm{dL}$ (diagnostic of thalassaemia trait), the couple are referred to a local designated health centre for genetic counselling. At-risk couples attend as many counselling sessions as they need to reach an informed decision about marriage (an average of 2.5 sessions, range $1-5$ ). Those who marry after counselling are referred to their local health centres or health houses for follow up until they have completed their family (24). Recently, there has been great success in the field of bone-marrow transplantation of thalassaemia major patients in the Islamic Republic of Iran (25), but obviously improving the screening programmes is a better way to deal with the issue than this complicated and expensive procedure.

To the authors' knowledge, there are no reports of iron-deficiency anaemia, G6PD and $\beta$-thalassaemia trait in migrating nomads from other countries with which to compare out results.

\section{Conclusions}

According to our results, we should be aware of the signs and symptoms of anaemia and common haematological disorders associated with anaemia (such as G6PD) in this population. The relatively high prevalence of $\beta$-thalassaemia trait seems to be a major potential risk in our area and a careful application of the Iranian thalassaemia programme seems to be needed. As iron-deficiency anaemia is a prevalent disease in migrating Arab nomads, establishment of educational programmes for these tribes is necessary. Early diagnosis and treatment is mandatory in the prevention of mortality and morbidity in this neglected population and we call on the Ministry of Health to pay special attention to this group.

\section{Acknowledgements}

Funding: the authors would like to thank the Office of the Vice Chancellor for Research of Shiraz University of Medical Sciences for financial support of this study, Fars Nomadic Organization for providing the facilities for presence of the research group in the region.

Competing interests: None declared.

\section{References}

1. Alebouyeh M. Pediatric hematology and oncology in Iran. Pediatr Hematol Oncol. 2005 Jan-Feb;22(1):1-9. PMID:15770826

2. Caro JJ, Ward A, Green TC, Huybrechts K, Arana A, Wait S, et al. Impact of thalassemia major on patients and their families. Acta Haematol. 2002;107(3):150-7. PMID:11978936

3. Tantawy AA, Andrawes NG, Ismaeil A, Kamel SA, Emam W. Prevalence of Xmnl Ggamma polymorphism in Egyptian patients with beta-thalassemia major. Ann Saudi Med. 2012 Sep-Oct;32(5):487-91. PMID:22871617

4. Karimi $M$, Yarmohammadi H, Farjadian S, Zeinali $S$, Moghaddam Z, Cappellini MD, et al. Beta-thalassemia intermedia from southern Iran: IVS-II-1 (G->A) is the prevalent thalassemia intermedia allele. Hemoglobin. 2002 May;26(2):147-54. PMID:12144057

5. Samavat A, Modell B. Iranian national thalassaemia screening programme. BMJ. 2004 Nov 13;329(7475):1134-7. PMID:15539666

6. Kazal LA Jr. Prevention of iron deficiency in infants and toddlers. Am Fam Physician. 2002 Oct 1;66(7):1217-24. PMID:12387433
7. Hedayat S, Rahbar S, Mahboobi E, Ghaffarpour M, Sobhi N. Favism in the Caspian littoral area of Iran. Trop Geogr Med. 1971 Jun;23(2):149-57. PMID:5568540

8. Cardoso MA, Scopel KK, Muniz PT, Villamor E, Ferreira MU. Underlying factors associated with anemia in Amazonian children: a population-based, cross-sectional study. PLoS One. 2012;7(5):e36341. PMID:22574149

9. Karimi M, Mehrabani D, Pasalar M, Afrasiabi AR, Mehravar Z, Reyhani I, et al. Thalassemia, iron and G6PD Deficiency in Lor migrating nomad children, southern Iran. Iranian Red Crescent Medical Journal. 2010;12(4):441-5.

10. Mehrabani D, Pasalar M, Afrasiabi A, Mehravar Z, Reyhani I, Hamidi R, et al. Frequency of thalassemia, iron and glucose6phosphate dehydrogenase deficiency among Turkish migrating nomad children in Southern Iran. Acta Med Iran. 2009;47(1):20-4.

11. Kadivar MR, Yarmohammadi H, Mirahmadizadeh AR, Vakili M, Karimi M. Prevalence of iron deficiency anemia in 6 months to 5 years old children in Fars, Southern Iran. Med Sci Monit. 2003 Feb;9(2):CR100-4. PMID:12601296 
12. Karimi M, Kadivar R, Yarmohammadi H. Assessment of the prevalence of iron deficiency anemia, by serum ferritin, in pregnant women of Southern Iran. Med Sci Monit. 2002 Jul;8(7):CR488-92. PMID:12118195

13. Jain S, Chopra H, Garg SK, Bhatnagar M, Singh JV. Anemia in children: early iron supplementation. Indian J Pediatr. 2000 Jan;67(1):19-21. PMID:10832215

14. Assefa S, Mossie A, Hamza L. Prevalence and severity of anemia among school children in Jimma Town, Southwest Ethiopia. BMC Hematology. 2014;14(1):3. PMID: 24433408.

15. Bouyou-Akotet MK, Mawili Mboumba DP, Kendjo E, Mbadinga F, Obiang-Bekale N, Mouidi $\mathrm{P}$, et al. Anaemia and severe malarial anaemia burden in febrile Gabonese children: a nine-year health facility based survey. J Infect Dev Ctries. 2013 Dec;7(12):983-9. PMID:24334946

16. Caballo Roig N, García P, Valdemoro M, del Castillo ML, Santos Tapia M, González Vargaz A, et al. Prevalencia de anemia en ninos y adolescentes de Madrid. [The prevalence of anemia in the children and adolescents of Madrid.] An Esp Pediatr. 1993 Sep;39(3):219-22. PMID:8250435

17. Merrill RD, Shamim AA, Ali H, Labrique AB, Schulze K, Christian $P$, et al. High prevalence of anemia with lack of iron deficiency among women in rural Bangladesh: a role for thalassemia and iron in groundwater. Asia Pac J Clin Nutr. 2012;21(3):416-24. PMID:22705433

18. Inati A, Abbas HA, Boumitri C, Tecle N. Prevalence of glucose6-phosphate dehydrogenase deficiency among neonates at a tertiary care centre in Lebanon. J Med Screen. 2012 Jun;19(2):103-4. PMID:22554801
19. Al-Nood HA, Bazara FA, Al-Absi R, Habori MA. Glucose6-phosphate dehydrogenase deficiency among male blood donors in Sana'a city, Yemen. Oman Med J. 2012 Jan;27(1):469. PMID:22359725

20. Phompradit P, Kuesap J, Chaijaroenkul W, Rueangweerayut R, Hongkaew Y, Yamnuan R, et al. Prevalence and distribution of glucose-6-phosphate dehydrogenase (G6PD) variants in Thai and Burmese populations in malaria endemic areas of Thailand. Malar J. 2011;10:368. PMID:22171972

21. Al-Jaouni SK, Jarullah J, Azhar E, Moradkhani K. Molecular characterization of glucose-6-phosphate dehydrogenase deficiency in Jeddah, Kingdom of Saudi Arabia. BMC Res Notes. 2011;4:436. PMID:22018328

22. Jameela S, Sabirah SO, Babam J, Phan CL, Visalachy P, Chang $\mathrm{KM}$, et al. Thalassaemia screening among students in a secondary school in Ampang, Malaysia. Med J Malaysia. 2011 Dec;66(5):522-4. PMID:22390120

23. Genc A, Tastemir Korkmaz D, Buyukleyla M, Celiker M. Prevalence and molecular analysis of $\beta$-thalassemia in Adiyaman, Turkey. Hemoglobin. 2012;36(2):131-8. PMID:22356097

24. Christianson A, Streetly A, Darr A. Lessons from thalassaemia screening in Iran. BMJ. 2004 Nov 13;329(7475):1115-7. PMID:15539644

25. Ramzi M, Nourani H, Zakernia M, Hamidian Jahromi AR. Hematopoietic stem cell transplantation for beta-thalassemia major: experience in south of Iran. Transplant Proc. 2004 Oct;36(8):2509-10. PMID:15561298 